\title{
SOME EFFECTS OF PROPRANOLOL ON THE CARDIOVASCULAR RESPONSES OF THE MONKEY TO SIMULATED SUBARACHNOID HAEMORRHAGE *
}

\author{
J.W.R. McINTYRE, M.R.C.s., L.R.C.P., K.C. PetruK, M.D., \\ B.K.A. WEIR, M.D. AND T.R. OvERTON, PH.D. $\dagger$
}

\begin{abstract}
SUBARACHNOT HAEMORRHAGE HAS BEEN ASSOCIATED with electrocardiographic changes in $n=$ nd in the experimental animal. ${ }^{1,2}$ These may vary greatly in character and anngst them have been changes consistent with increased activity of the sympathetic nervous system. Structural changes in the myocardium have been described that could be produc ad by a period of sympathetic nervous system overactivity $^{\vec{a}}$ and increased tissue catecholamine levels have been measured following subarachnoid haemorrhage and other forms of stimulation of the brain in the laboratory animals. ${ }^{4}$ The importance of the catecholamines is also suggested by the abolition of encephalogenic cardiac arrhythmias in dogs following treatment with reserpine. ${ }^{5}$ The portion of sympathetic nervous activity mediated by $\beta$-receptor stimulation has received some attention, not only because of the intrinsic interest in the mechanism of these arrhythmias, but because of the effect of rapid arrythmias on cardiac output and the possible reduction of cerebral blood flow. Accordingly it seemed of interest to study the effects of the prior administration of propranolol on such changes in cardiac rhythm and cerebral blood flow as might occur following simulated subarachnoid haemorrhage in the monkey.
\end{abstract}

\section{Metron}

Rhesus monkeys were sedated with intraperitoneal sodium pentobarbital 50 $\mathrm{mg} / \mathrm{kg}$ body weight and the trachea was intubated. Anaesthesia was maintained with a mixture containing thirty per cent of oxygen in nitrous oxide. The animals were paralyzed with $d$-tubocurarine, artificially ventilated with a Harvard variable phase ventilator and then surgical preparations were made for measurements of cerebral blood flow, intracranial pressure, and systemic arterial pressure. During this period fluid balance was maintained, blood gases were measured at regular intervals, and normal body temperature was maintained. Four to six hours later, at which time cerebral blood flow was stable and a multichannel Grass encephalograph indicated brain activity consistent with light nitrous oxide anaesthesia, arrangements were made to simulate a subarachnoid haemorrhage. This was done by inserting a needle through a hole in the midline of the skull at a point $0.5 \mathrm{~cm}$ cephalad to the nasion and manipulating its tip alone the floor of the anterior fossa to a point about $0.75 \mathrm{~cm}$ anterior to the tuberculum sellae so that it lay in the

\footnotetext{
-Supported by Alberta Heart Foundation, Grant No. 55-29063-930.

tDepartment of Anaesthesia and Divisions of Neurosurgery and Biomedical Engineering,
} University of Alberta, Edmonton, Alberta, Canada. 
subarachnoid space dorsal to the planum sphenoidale. This is the region which would be contaminated by blood released from an aneurysm in the vicinity of the Circle of Willis. The position of the needle was confirmed by fluoroscopy and by leakage of cerebrospinal tluid. The manoeuvre produced no electroencephalographic, arterial pressure, or electrocardiographic changes. Either saline or propranolol $0.03 \mathrm{mg} / \mathrm{kg}$ was administered intravenously at a rate of $0.01 \mathrm{mg} / \mathrm{kg} / \mathrm{min}$. Five minutes later a subarachnoid haemorrhage was sirnulated by injecting $4.0 \mathrm{ml}$ of fresh autogenous blood through the needle over a period of twenty seconds. At autopsy the gross characteristics closely resembled the pathological state in patients succumbing from rupture of an aneurysm.

Cardiac rhythm and femoral arterial pressure were continuously monitored on Electronics for Medicine equipment. The technique employed for measuring cerebral blood flow was that described by Ingvar Lassen and Hoedt Rasmussen ${ }^{6,7.8}{ }^{133}$ Xenon $(0.5-1.0 \mathrm{mCi})$ dissolved in $0.5 \mathrm{mt}$ of sterile saline was injected during a two to three second period through a small catheter inserted into the lingual artery. Extra-cerebral contamination with ${ }^{138}$ Xenon was minimized by ligation of the external carotid artery distal to the origin of the lingual artery. The clearance of ${ }^{133}$ Xenon from the brain was measured simultaneously for a tenminute period by each of two collimated scintillation detectors placed symmetrically over the right and left parietal regions. The signal output from each one inch diameter, half inch think, integral line $\mathrm{NaI}(\mathrm{Tl})$ crystal was amplified, analyzed and stored over multiplexed high speed time sequential inputs (multiply buffered device) into a 400 word magnetic core memory. Punched paper tape data output from the 400 word memory allowed immediate access to calculated flows through an on-site laboratory computer system.

Calculation of cBF by compartmental, stochastic, and initial slope index methods was made. The compartmental analysis (c) assumes that the semilogarithmic replot of the clearance curve can be represented by two exponential components. From these two phases blood flow in the gray and white matter is calculated. The relative weights of the two components are determined from the intercepts of the two slopes at zero time. Utilizing the perfusion rates and relative weights of each tissue, the weighted mean cerebral blood flow for the tissue under observation can be calculated by the formula:

$$
F_{a}=W g \times f g+W w \times f w \quad \mathrm{ml} / 100 \mathrm{gm} / \mathrm{min} .
$$

The stochastic method (H/A) formulated mathematically by Zeirler ${ }^{9}$ can be applied to calculate the mean flow values from the linear washout curve according to the formula:

$$
F_{H / \Lambda}=\frac{\left(H_{0}-H_{10}\right) \times \lambda \times 100}{A_{10}-\text { Background }} \mathrm{ml} / 100 \mathrm{gm} / \mathrm{min}
$$

where $H_{0}$ corresponds to all the indicator particles to be cleared and $H_{10}$ the number of particles remaining after ten minutes of clearance. $A_{10}$ is determined by integrating the counts recorded during ten minutes and $\lambda$ denotes the mean tissue: blood solubility for ${ }^{138}$ Xenon. 
The initial slope index (Is) method utilizes the gradient of the first 1.5 to 2 minutes of the logarithmic clearance curve. ${ }^{10,11}$ An estimate of mean cerebral blood flow can be rapidly assessed by the equation:

$$
F_{I S}=\lambda g \times 2.30 \times D \quad \mathrm{ml} 100 \mathrm{gm} / \mathrm{min}
$$

$\lambda g$ corresponds to the ${ }^{13}$ Xenon partition coefficient for gray matter and $D$ represents the numerical value of the slope of the curve.

The computer programme employed for calculation of the pre-haemorrhage flows incorporated a correction factor (c) for $\mathrm{PCO}_{2}{ }^{8}$ In view of the uncertainty regarding the effect of arterial $\mathrm{PCO}_{2}$ on cerebral circulation following acute apoplexy this factor was omitted from calculation of the post-haemorrhage flows. Every endeavour was made to maintain the arterial $\mathrm{PCO}_{2}$ within the normal range during this period, although some of the animals were in a state of slight metabolic acidosis during the course of the experiment.

\section{Results}

Some data regarding the state of the animals prior to the introduction of subarachnoid blood and approximately forty-five minutes later appear in Table I. There was a significant difference in the temperature of the two groups at the forty-five minute period but in other respects the two groups are comparable.

The cardiac rhythm was analyzed for a two-minute period following the introduction of blood and in two animals in the propranolol group no alterations in rhythm occurred. Details of the arrhythmias that did develop appear in Table II. Sinus arrhythmia was frequent and in the propranolol group the RR intervals differed by periods of up to 0.8 seconds. T-wave changes were common and usually

TABLE I

\begin{tabular}{|c|c|c|c|c|}
\hline & \multicolumn{2}{|c|}{$\begin{array}{c}\text { Prior to subarachnoid } \\
\text { haemorrhage }\end{array}$} & \multicolumn{2}{|c|}{$\begin{array}{l}45 \text { minutes } \\
\text { after subarachnoid } \\
\text { haemorrhage }\end{array}$} \\
\hline & $\begin{array}{c}\text { Saline } \\
\text { gtoup } \\
\text { n6 }\end{array}$ & $\begin{array}{l}\text { Propranolol } \\
\text { group } \\
\text { n6 }\end{array}$ & $\begin{array}{l}\text { Saline } \\
\text { group } \\
\text { n6 }\end{array}$ & $\begin{array}{l}\text { Propranolol } \\
\text { group } \\
\text { n6 }\end{array}$ \\
\hline $\begin{array}{l}\text { pH } \\
\text { Wean }\end{array}$ & $\begin{array}{r}7.39 \\
\pm 0.04\end{array}$ & $\begin{array}{r}7.34 \\
\pm 0.09\end{array}$ & $\begin{array}{r}7.39 \\
\pm 0.01\end{array}$ & $\begin{array}{r}7.37 \\
\pm 0.01\end{array}$ \\
\hline $\begin{array}{l}\text { Pcor } \\
\text { (minHg) } \\
\text { Mean } \\
\text { SD }\end{array}$ & $\begin{array}{r}42 \\
\pm 4\end{array}$ & $\begin{array}{r}41 \\
+4\end{array}$ & $\begin{array}{r}40 \\
\pm 4\end{array}$ & $\begin{array}{r}40 \\
\pm 5\end{array}$ \\
\hline $\begin{array}{l}\mathrm{PO}_{\mathrm{q}} \\
\text { Mean } \\
\text { So }\end{array}$ & $\begin{array}{r}153 \\
\pm 48\end{array}$ & $\begin{array}{r}134 \\
\pm 33\end{array}$ & $\begin{array}{r}131 \\
\pm 32\end{array}$ & $\begin{array}{r}144 \\
\pm 34\end{array}$ \\
\hline $\begin{array}{l}\text { Esophageal temperatire } C^{\circ} \\
\text { Mean } \\
\text { SD }\end{array}$ & $\begin{array}{r}36.8 \\
\pm 0.5\end{array}$ & $\begin{array}{r}36.4 \\
\pm 0.9\end{array}$ & $\begin{array}{r}37.4 \\
\pm 0.6\end{array}$ & $\begin{array}{r}36.3 \\
\pm 0.4\end{array}$ \\
\hline
\end{tabular}


TABLE II

Incidence of Cardiac Arreythmias During Two Minutes FOLLOWING THE BEGINNING OF INTRODUCTION OF SUBARACHNOID BLOOD

\begin{tabular}{|c|c|c|}
\hline & $\underset{n 6}{\text { Saline }}$ & $\begin{array}{c}\text { Propranolol } \\
\mathbf{n 6}\end{array}$ \\
\hline No change & 0 & 2 \\
\hline Sinus arrhythmia & 2 & 4 \\
\hline \multicolumn{3}{|l|}{ A.v junctional rhythm } \\
\hline$<5$ isolated complexes & 3 & 2 \\
\hline multiple complexes & 1 & $\overrightarrow{0}$ \\
\hline \multicolumn{3}{|l|}{ Premature ventriculat systoles } \\
\hline$<5$ isolated complexes & 1 & 0 \\
\hline bigemini & 0 & 1 \\
\hline sequences of more than 3 complexes & 1 & 1 \\
\hline$v$ waves & 0 & $\hat{\mathbf{1}}$ \\
\hline T elevation or inversion & 3 & 5 \\
\hline
\end{tabular}

consisted of an increase in amplitude. The monkey in the propranolol group that developed sequential ventricular extrasystoles received propranolol twenty-eight minutes before the simulated haemorrhage, because of technical difficulties. The other five animals were subjected to haemorrhage within five to ten minutes of the injection of the drug.

The changes of pulse rate and systemic blood pressure that occurred in the two groups appear in Tables III to VI. There was a transient decrease in pulse rate in the group that did not receive propranolol. The propranolol group also exhibited cardiac slowing, but this appeared to be of greater magnitude and longer duration. There was an increase in systemic blood pressure following the baemorrhage in both groups, but this was significantly greater after one minute had elapsed, and during the ensuing four minutes, in the propranolol group.

The prehaemorrhage cerebral blood flow measurements, with which the posthaemonhage blood flows were compared, were made prior to the injection of propranolol. These, together with the posthaemorrhage flows, appear in Table VII. In the saline group there was no significant difference between the pre- and posthaemorrhage flows. In the propranolol group there was a significant reduction in the posthaemorrhage blood flow, calculated by the compartmental $(p<0.025$, $p<0.025)$, and stochastic $(p<0.25, p<0.005)$ methods.

The monkeys exhibited electroencephalographic changes beginning approximately 10 seconds following the start of blood injection. The EEG became flat at I5-20 seconds and remained isoelectric for 30-120 seconds. Giant amplitude slow waves then appeared and lasted up to 5 minutes. Electrical activity gradually reverted towards normal, although there was generally increased sporadic delta and theta activity as compared to the baseline trace. In the animals showing a progressive reduction in $\mathrm{CBF}$, progressive loss of amplitude and decreased frequency was exhibited.

Satisfactory measurement of intracranial pressure was not achieved during the course of these experiments but in previous experiments, using a similar technique, lumbar cerebrospinal fluid pressure reached a mean value of $120 \mathrm{~mm} \mathrm{Hg}$ (SD 76) at the termination of the injection of blood. ${ }^{12}$ 

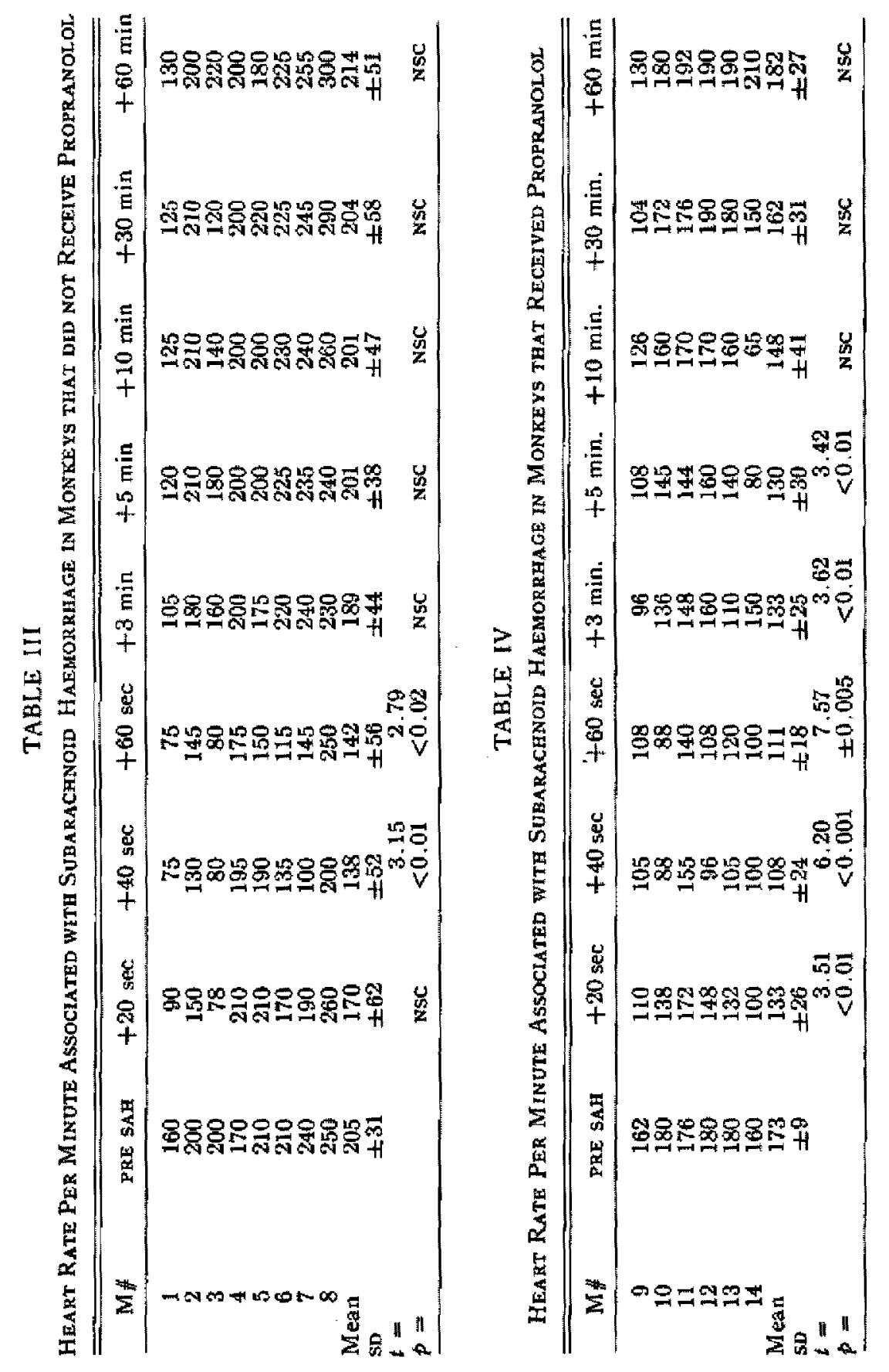

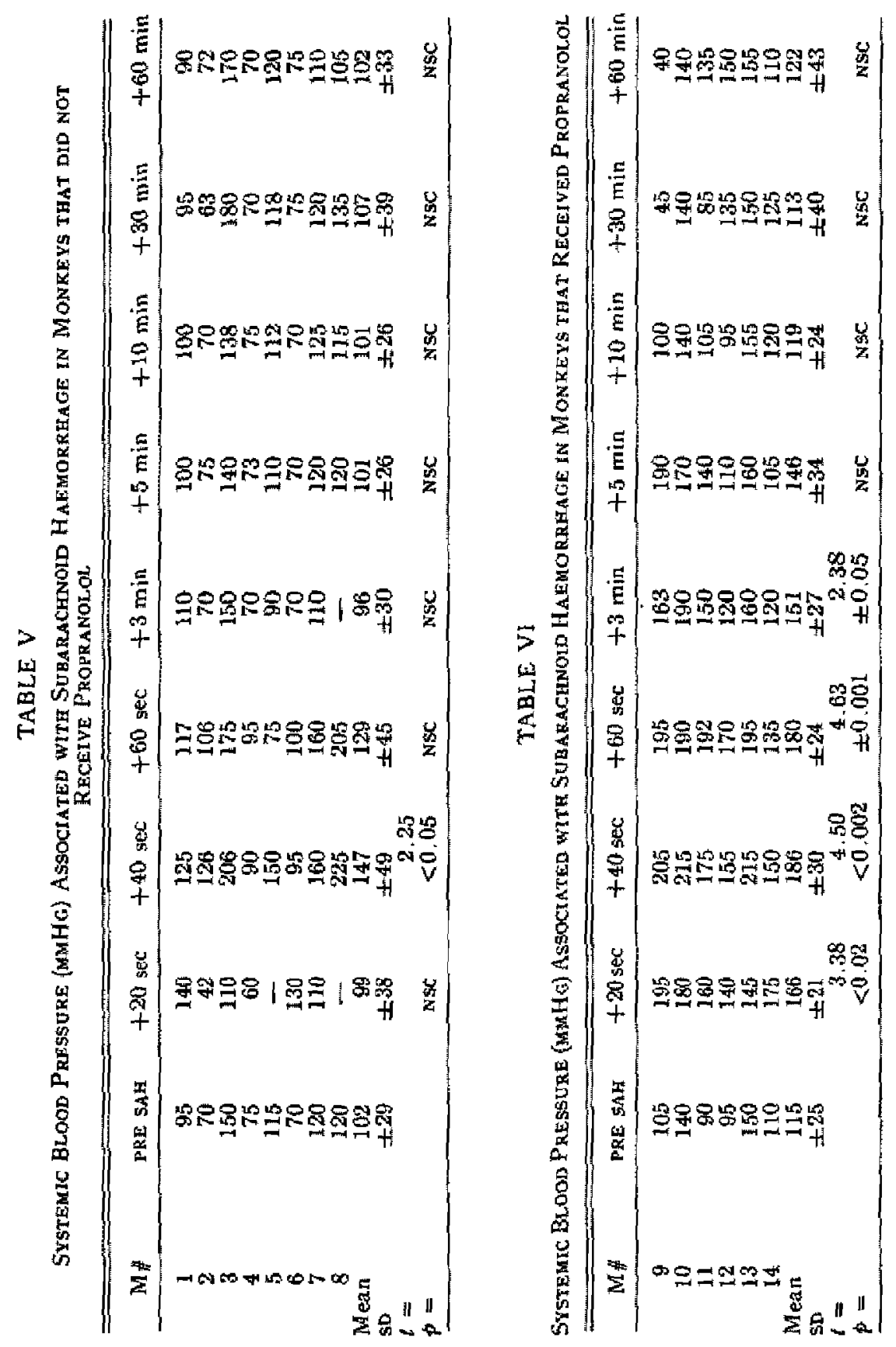
TABLE VII

Ceregrai. Blood Flows (me/100 gm/min) Associated with Subarachnoid Haemorrhage in Mon Keys that did and did not Receive Propranolol

\begin{tabular}{|c|c|c|c|c|c|c|c|c|c|}
\hline & \multirow{2}{*}{\multicolumn{3}{|c|}{ Prehaemorthage CBF }} & \multicolumn{6}{|c|}{ Posthaemorrhage cBF } \\
\hline & & & & & $+5 \mathrm{~m}$ & & +1 & $45 \mathrm{~min}$. & \\
\hline & CC & $\mathrm{H} / \mathrm{AC}$ & ISC & $\mathbf{c}$ & H/A & Is & $\mathrm{c}$ & $\mathrm{H} / \mathrm{A}$ & Is \\
\hline $\begin{array}{l}\text { Saline } \\
\text { Monkey No. } 2\end{array}$ & \multirow{6}{*}{$\begin{array}{r}56 \\
\pm 11 \\
47 \\
\pm 4 \\
51 \\
\pm 12 \\
54 \\
\pm 8 \\
44 \\
\pm 14 \\
40 \\
\pm 8\end{array}$} & 83 & 87 & 55 & 76 & 82 & 42 & 54 & 51 \\
\hline 4 & & $\begin{array}{r}57 \\
\pm 6\end{array}$ & $\begin{array}{r}57 \\
\pm 10\end{array}$ & 92 & 110 & 121 & 40 & 64 & 67 \\
\hline 5 & & $\begin{array}{l}74 \\
\pm 3\end{array}$ & $\begin{array}{r}78 \\
\pm 5\end{array}$ & 60 & 76 & 76 & 72 & 69 & 67 \\
\hline 6 & & $\begin{array}{r}62 \\
\pm 3\end{array}$ & $\begin{array}{r}59 \\
\pm 4\end{array}$ & 44 & 44 & 43 & 43 & 44 & 43 \\
\hline 7 & & $\begin{array}{r}61 \\
\pm 18\end{array}$ & $\begin{array}{r}70 \\
\pm 18\end{array}$ & 54 & 57 & 56 & 50 & 63 & 60 \\
\hline$\pi$ & & $\begin{array}{r}39 \\
\pm 8\end{array}$ & $\begin{array}{r}41 \\
\pm 6\end{array}$ & 26 & 22 & 20 & 11 & 13 & 14 \\
\hline $\begin{array}{l}\text { Propranolol } \\
\text { Monkey No. } 9\end{array}$ & $\begin{array}{r}38 \\
\pm 6\end{array}$ & $\begin{array}{r}45 \\
\pm 12\end{array}$ & $\begin{array}{r}48 \\
\pm 10\end{array}$ & 7 & 7 & 15 & 4 & 3 & 9 \\
\hline 10 & 48 & 68 & $\begin{array}{r}79 \\
+4\end{array}$ & 41 & 49 & 47 & 33 & 37 & 43 \\
\hline 11 & $\begin{array}{r}47 \\
+7\end{array}$ & $\begin{array}{r}55 \\
+12\end{array}$ & $\begin{array}{r}55 \\
+18\end{array}$ & 38 & 34 & 34 & 30 & 22 & 14 \\
\hline 12 & $\begin{array}{r}61 \\
\pm 9\end{array}$ & $\begin{array}{r}78 \\
\pm 14\end{array}$ & $\begin{array}{r}85 \\
\pm 16\end{array}$ & 51 & 65 & 76 & 48 & 51 & 51 \\
\hline 13 & $\begin{array}{r}59 \\
+8\end{array}$ & $\begin{array}{r}69 \\
+4\end{array}$ & $\begin{array}{r}69 \\
\end{array}$ & 38 & 34 & 39 & 43 & 32 & 31 \\
\hline 14 & $\begin{array}{r}59 \\
\pm 2\end{array}$ & $\begin{array}{r}70 \\
\pm 6\end{array}$ & $\begin{array}{r}82 \\
\pm 11\end{array}$ & 26 & 27 & 33 & 22 & 28 & 40 \\
\hline
\end{tabular}

\section{Discussion}

A relationship between some of the cardiac arrhythmias associated with subarachnoid haemorrhage and an effect of the sympathetic nervous system on the heart is well documented. ${ }^{5,13,14}$ Many of these arrhythmias are likely to be mediated by $\beta$-receptor mechanisms and propranolol is an effective drug in the prophylaxis and treatment of such arrhythmias. ${ }^{15,18}$ Thus it seems likely that the failure to abolish arrhythmias of ventricular origin in the propranolol group of monkeys was, at least in part, due to insufficient quantity of the drug rather than inappropriate selection of the drug. Coltart $e t a l .{ }^{17}$ have measured the plasma propranolol associated with suppression of automatically occurring ventricular ectopic beats in adult humans. The drug was infused at a rate of $1.0 \mathrm{mg} /$ minute (a quantity similar on a body weight basis to that used in the experiments reported here) - but for suppression of arrhythmias for a two-minute period dosages up to $29 \mathrm{mg}$ were required in eight out of twelve cases. The dosage of propranolol employed in the present experiments was limited to $0.03 \mathrm{mg} / \mathrm{kg}$ because preliminary observations showed that higher dosage was likely to produce a significant difference in systemic blood pressure between the two groups. Offerhaus and Van Gool ${ }^{4}$ noted the effectiveness of $1.0 \mathrm{mg} / \mathrm{kg}$ in abolishing existing arrhythmias for five minutes in rabbits, but also noted that pretreatment of the animals with the dosage apparently necessary to block the arrhythmias produced a gradual fall in systemic arterial pressure. This 
could be of a magnitude sufficient to threaten the maintenance of nomnal cerebral blood How. Although the half life of propranolol in the body is two hours ${ }^{15}$ no attempt was made to measure such effect as the drug in the dosage used may have on cerebral blood flow, because the simulated haemorrhage would have been unduly delayed. Little inference of a reduction in cerebral blood flow can be drawn from the reports of clinical use of the drug and Solti et al.$^{18}$ have demonstrated in dogs that propranolol $0.2 \mathrm{mg} / \mathrm{kg}$ has no effect on cerebral blood flow. Thus the assumption is made that the reduction in cerebral blood flow following the simulated haemorrhage in the propranolol group is due to an altered response to the injection of blood rather than a pre-existing reduction in flow produced by propranolol. Introduction of blood into the subarachnoid region as employed in these experiments has rapid cardiovascular effects derived from tactile and pressure events within the cranium and responses to these occurring in the rest of the body. The limited number of physiological functions measured in these experiments precludes more than speculation regarding the reason for the reduction in flow of the animals that had received propranolol. The peripheral actions of the drug may be the most important in this context, if maintenance of cerebral blood flow under adverse circumstances of subarachnoid haemorrhage is in its initial stage due in part to adequate sympathomimetic responses of the heart. Propranolol would impair this homeostatic mechanism. Alternatively, or perhaps in addition, propranolol may have a role in modifying the local responses of the cerebral vasculature and indirectly influencing cerebral blood flow. The complexities of $\beta$-adrenergic mechanisms and vascular smooth muscle form part of a recent review by Somlyo et al. ${ }^{18}$

In conclusion, it appears that propranolol used in the manner described fails to ensure protection against ventricular arrhythmias induced by subarachnoid haemorrhage and may increase the danger of vagal stimulation. The changes in cerebral blood flow indicate the need for further elucidation of the effects of various forms of intracranial stimulation on cerebral blood flow in the presence of propranolol. During neurosurgical anaesthesia the effect of rapid arrhytbmias on cardiac output $^{20}$ may make their correction mandatory, but it seems possible that propranolol has a significant effect on intracranial haemodynamics during surgery and in the postoperative period.

\section{REFERENCES}

1. Wilkrns, R.H.; Axexander, J.A.; \& ODOM, G.L. Intracranial Arterial Spasm: A Clinical Analysis. J. Nenrosurg., 29: 121 (1968).

2. Krevs, K.E.; KemiLa, S.J.; \& Taxala, J.K. Electrocardiographic Changes in Cerebrovascular Accidents. Acta Med. Scand, 185: 327 (1969).

3. Connor, R.C.R. Heart Damage Associated with Intractamial Lesions. Brit. Med. J., 3: 29 (1968).

4. OfFerhaus, L. \& Van Goox, J. Electrocardiographic Changes and Tissue Catecholamines in Experimental Subarachnoid Haemorrhage. Cardiovasc. Res., 3: 433 (1969).

5. Eichbaum, F.W.; Gazetia, B.H.; \& Bissetil, P.C. Mechanism of Encephalogenic Heart Injury. Zeitschrift fur die Gesamte Experimentelle Medizin, 139: 735 ( 1965).

6. Incvar, D.I. \& LAsSEN, N.A. Regional Blood Flow of the Cerebral Cortex Determined by Krypton 85. Acta Physiol. Scand, 54: 325 ( 1962 ).

7. I.assen, N.A.; Hormt-Rasmussen, $X_{+}$; \& Sorenson, S.C. Regional Cerebral Blood Flow in Man Determined by Krypton 85. Neurol. (Minneap.) 13: 719 (1963).

8. Hoedt-Rinsmussen, K. Regional Cerebral Blood Flow. The Intra-arterial Injection Method. Thesis: University of Copenhagen ( 1967), Mundsgand Publication (1967). 
9. Zemlen, K.L. Equations for Measuring Blood Flow by External Monitoring of Radioisotopes. Circ. Res. 16: 309 (1965).

10. Hoedt-Rasmussen, K.; Sxinhoj, E,; Paulson, D. Regional Cerebral Blood Flow in Acute Apoplexy. Arch Neurol. (Chicago), $17: 271$ (1967).

11. PavLson, O.B. Regional Cerebral Blond Flow in Middle Cerebral Artery Occlusion. Scand. J. Clin. Lab. Invest., Suppl. I02, xIr.A. (1968).

12. McIntyre, J.W.R.; Dobson, D.; Wer, B.K.A.; West, R.; \& Overton, T.R. Monitoring under Anaesthesia, with Reference to Subarachnoid Haemorrhage, and the $r$-Wave as an Electrocardiographic Manifestation. Canad. Anaesth. Soc. J, 18: 293 (1971).

13. Eichbaum, F.W.; Gazetta, B.H.; BissetTi, P.C.; \& Penerra, C.B. Electrocardiographic Disturbances Following Acute Increase of Intracranial Pressure. Zeitschrift fur die Gesamte Experimentelle Medizin, 139: 721 (1965)

14. Pook, ].L. Vasocardiac Effects of the Circle of Willis. Arch. of Neur. \& Psych., 78, 355 (1957).

15. Frtzceracd, J.D. Perspectives in Adrenergic Beta Receptor Blockade. Clin. Pharm. \& Therap, 10: 292 (1969).

16. Groson, D. \& Sowton, E. The use of Beta-adrenergic Receptor Blocking Drugs in Dysthythmias. Progress in Cardiovasc. Diseases, 12: 16 (1969).

17. Colsart, D.J.; Grason, D.G.; \& Shand, D.G. Plasma Propranolol Levels Associated with Suppression of Ventricular Ectopic Beats. Brit. Med. J, 1: 490 (1971).

18. Solti, F; Krasznal, I.; Rev, J.; \& NagY, J. Acta Physiologica Scientiarium Hungaricae, 38: $85(1970)$.

19. Soml yo, A.P. \& Somz Yo, A.V. Vascular Smooth Muscle. Pharm. Rev., 22: 249 (1970).

20. Whicht, J.S; FABtaN, J.; \& Epsteis, E.J. Immediate Effect on Cardiac Output of Reversion to Sinus Rhythm from Rapid Arrhythmias. Brit. Med. J., 3: 315 (1970). 